\title{
FORECASTING THREATS TO THE BALTIC SEA REGION COOPERATION SECURITY IN THE PERIOD OF LITHUANIA INTEGRATING INTO NATO AND THE EU
}

\author{
Antanas Makštutis \\ The General Jonas Žemaitis Military Academy of Lithuania, \\ BOX - 812, LT-2055 Vilnius, Lithuania \\ E-mail:Malgas@mail.lt
}

Received: 15 Sept 2003; accepted 3 Nov 2003

\begin{abstract}
The work deals with the global economic factors of the world that have an impact on the development of the country's economy and national market as well as on the regional cooperation security under the conditions of Lithuania's integration into NATO and the European Union (EU). Methodological principles of research of internal threats of the regional cooperation security, methodics and methods of their implementation are provided. Forecast is made of the tendencies of human activity efficiency in dependence upon which a description is given of the human life quality and the rational use of resources, the GDP changes and tendencies of competitiveness in the national, EU and world markets. The internal environment for the regional cooperation security in time and space is modelled.
\end{abstract}

Keywords: national state, development, factors, environment, resources, market, society, capital, efficiency, progress, democracy, national security

\section{Introduction}

Delopment and progress of policy, the social area, economy, technology and other fields under the conditions of globalization are noted for the still more expanding scale of activities and its mass development. The impact of the scales of activities and of their results manifests itself as follows [1]: new results of the integral factors of the political, social and economic environment are spreading rapidly and become massive; more numerous projects of global economy are formed and implemented, and they are based on the political decisions relating to the development of the national state and the world community, since finance, material and human resources are concentrated in these projects, and the scope of activities is oriented towards the still greater number of major spaces.

The balanced development of the economy and national market of a separate state depends on the political, economic and social environment of the country. This environment gets changed due to integration and globalization processes, during which the integral factors of the development of the state and society are being formed. Under the conditions of Lithuania's integration into NATO and the EU, it becomes still more important to forecast the integral dependency of the development of political, economic and social factors within the country, to determine the methodological principles for researching internal threats of the regional cooperation security, and to describe methodics and methods of their implementation [2]. The solution of the formulated objective and its implementation tasks at a national state level is aggravated by the general methodology of the free market development and the real results of the world global economy in time and space (in Lithuania, the Baltic Sea region, NATO and the EU common space). On the other hand, these results are characterized by "free movement" [3] under the conditions of globalization, the constituent parts of which are provided in Fig. 1.

"Free movement" is the general integral result of integration and globalization in time and space. Therefore the functions of time and space change the vision and mission of the development of the national 


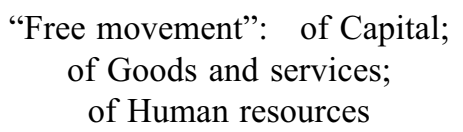

Fig 1. The principal model of free market

state and society, form the complex and comprehensive tasks of the internal environment [4].

The urgency of the theme implies that under such conditions each entity when forming its own policy cannot base itself on the absolute difference of models of power and security, which has not been investigated as of today and is not revealed in the scientific literature. The ensuing vagueness and non-security have a powerful impact on the internal national security policy of the development of the state and society [5]. Currently, the economy of the country and national market are at a crossroads, since our national product manufactured is non-competitive [6]. The state budget lacks funds for the development of human activities, whereas the legal acts of the country, the EU and NATO are not finally harmonized for ensuring the development of economy [7]. The results of research performed evidence that internal threats of Lithuania's national security are developing more rapidly as compared to external threats of the regional cooperation security [2], therefore prediction of changes in the integral factors is becoming still more important.

The objective of research is to analyze the effect of global economic factors on the internal threats of the regional cooperation security in Lithuania.

Research tasks are to identify the developmental tendencies of political, economic and social factors in the development of the country and society and the internal threats of national security.

Research object is the internal environment for the development of the country and society.

Research methodics is a monographic method used, for the implementation of which, analysis and synthesis, graphic, mathematical modelling, observation, data collection, systematization, and accumulation, as well as other integral methods are applied. With their help, scientific - practical investigations were conducted: analysis was made of the internal threats of the regional cooperation security under the conditions of Lithuania's integration into NATO and EU.

Work results cover the described methodological principles for researching internal threats of the regional cooperation security, methodics and methods for their implementation are presented, conclusions are formulated.

The main sources of information are the latest and newest scientific works in this field by Lithuanian and foreign authors, theoretical and practical results of international symposia and scientific conferences, official and statistical as well as other information published in the sources and in the internet, results of comprehensive research conducted and systematic material of their analysis.

\section{Modelling of the Environment for the Development of the State and Society}

Description of methodology of internal threats of the regional cooperation security of the development of the country and society and the preparation of assessment methodics as well as the formation of a model of internal threats is a long-term and complex process, since it is necessary to analyze the factors of the political, economic and social environment, to determine their integral dependency at the level of correlative relations [5].

The internal threats for the development of the national state and society are on the constant change in time and space, this meaning that they are developing from the past and integrate today into the existing political, economic and social environment. This environment is characterized by the three main groups of factors that are described by political, economic and social integral factors [2]. A principal model of integral dependency of political, economic and social factors is presented in Fig. 2.

Political factors; Economic factors; Social factors

Fig 2. The principal model of integral factors of the environment

The development of these factors and their integral dependency is under direct effect of the system of management of the national state institutions and selfmanagement administration system, since the balanced development of the economy of the country and the national market depends on the results of public administration: the life quality of people (the integral indicator of public development in time and space in Lithuania or any other individual state, the EU, and the world) [8]. The general development of the state and society is under the influence of global economic factors, whereas the regional cooperation upon 
Lithuania's integration into NATO and the EU is the result of the development of non-linear processes that depends insignificantly on the direct effect of the activity of a separate person and his family, and vice versa, since the human life, activity and his family development are constantly affected by the political, economic and social environment of non-linear processes in place (in the territory of Lithuania) [3].

It is identified that we do not have theoretical and practical opportunities to calculate the efficiency of relative dependency of the development of the global economy of the world and national economy, as we face the global systems of the world development, while the methodology for forecasting of their development strategy and even a hypothesis have not been prepared [5]. However, the methodology for forecasting of the world community development provides the opportunity for studying the global systems by splitting them into less global systems [8] that are provided in Fig. 3.

The System of development of: the State; Society; Organization; Family; Individual

Fig 3. The principal model of the global system

Such methodological principle creates real conditions for the precise formulation of the objective of research, tasks, the object of research, methods, and for forecasting of research results in time and space. With this principle applied, it is possible to present a model for the development of the national state and society [5], which is characterized by the environment and its constituent parts, presented in Fig.4.

Political environment; Economic Environment; Social environment

Fig 4. The principal model of the state development environment

The presented model for the development of the national state and society integrates all key macro- and microsystems that affect internal threats of the regional cooperation security in our country upon Lithuania's integration into NATO and the EU. Such a model is correct methodologically and methodically, since it corresponds to the main features of the national state [8], its place in the integral space of NATO and the EU as well as the world community at present and in future. The integral model presented constitutes methodological, methodical and practical measures for ensuring the development, balanced by progress and democracy, to accelerate the developmental processes of the national state and society in the internal and external environment, which is characterized by integral factors that will be further described [8].

Political environment is described by political factors, and these factors affect constantly the development balanced by progress and democracy at the level of integral results of the Comprehensive Management Self-management and Self-management Management System (CMSSMS) of the state (in the territory of Lithuania, human life and activity, family development, work of the collective in the organization) [2].

Management is the result of the activity of the employees of all state institutions (personnel of organizations), which is expressed by the system of the normative acts of the state ("NAS" - the Constitution, laws, subordinate legislation, and other instruments) [9]. The destination of "NAS" is to regulate the constant strengthening of the national security of the regional cooperation security upon Lithuania's integration into NATO and the EU: while enhancing democracy (through management) and progress to ensure the balanced development of the state and society as well as economy and national market in time and space [2].

Self-management is the result of the mutual activity of the collectives in the organizations, a separate person and his family (microsystems), which is expressed by labour activity - human interrelations that are based on the system of normative acts (nas) which they have prepared according to "NAS" [8]. Microsystems' "nas" include private documents of the individual and family, the system of documents relevant to the development of the organization, which do not contradict "NAS" and are undertaken to be executed within and outside the country. Destination of microsystems" "nas" is to regulate the constant strengthening of the national security of the regional cooperation security upon Lithuania's integration into NATO and the EU: while developing democracy (through self-management) and progress to ensure the labour activity balanced by the human life, development balanced by his family and constant optimization of the collective activity in the organization, using progress-balanced developmental results for the sustained modernization of the organization in time and space and the establishment of modern organizations in Lithuania [2].

Democracy is the equivalent between "NAS" and "nas", which stimulates the balanced development of progress and thus ensures changes in the life quality 
of Lithuanian people in time and space. These changes affect the development of internal threats (weaken or intensify them) [2]. The limits of democracy are distributed between anarchy and regime. At these extreme levels of democratic processes the internal threats to the development of the country and society are developing especially rapidly, since the balanced development of general progress slows down and the functional dependency between democracy and progress processes exists [8]. Progress has a typical structure of its own [2], which is presented in Fig. 5.

\section{New product; New materials, technologies,} means of activity; New labour efficiency

Fig 5. The principal model of progress structure

The use of progress reduces the internal threats in the country, since the real opportunities are created for people to develop their labour activities, this stimulating the balanced development of the country's economy and national market in time and space. The balanced development of the national economy and market results in the life quality of people, which forms the economic and social environment [6]. Economic environment is described by economic factors, which constantly affect the balanced development of the economy of the country and national market, upon which the tendencies for the development of internal threats depend, since the results of the development of the national and social economy are expressed by macro- and microeconomics indicators in the fixed time and place [8]. The values of these indicators are presented in the factual reports on human activity according to "NAS" and "nas". Integral results are fixed in the annual budget of the state and society development. Prospects of the balanced development of the state and society, tendencies for changes of internal threats as well as the integral environment of the state and society development depend on the factual results of human labour [2]. According to methodology and methodics of the management of the balanced development of the national state and society and its application methods, macro- and microsystem economic factors may be grouped in the sequence of forecast indicators of optimum activity [2], which are typical for all countries of the world both in time and space. All indicators are calculable quantities; they are provided in Fig.6.

The political and economic environment conditions the development of the regional cooperation security upon Lithuania's integration into NATO and the EU, balanced by the social environment of internal threats
State budget; Gross Domestic Product; Volumes of export; Volumes of import; Inflation; Income; Expenses; Investments; Cost price; Price; Profit; Money;

Natural, Material and Human resources; Other (integral)

Fig 6. The principal model of economic indicators of the state development

in time and space (in Lithuania, the EU, and the world) [2].

Social environment is described by social factors that are formed by human relations in the political and economic environment of the balanced development of the state and society [2]. Human relations in the society is communication, and cooperation covers the life and work of a separate individual, his family development, permanent optimization of the activity of the collective in the organization [2]. Integral results of human cooperation are expressed by the quality of human life in Lithuania and beyond the borders of its territory [10]. This integral result is under a direct effect of the development of our country and society balanced (or non-balanced) by political, economic, and social factors [11]. Social factors of the development of the state, society, the economy of the country, and national market are connected by time and space (Fig. 7) [2].

Development of : the country, county, city, district, township, village, society, family, individual;

Employment; Emigration; Immigration; Field: health, education and science, culture;

Life quality; Ecological balance;

Demographic changes; Other (integral)

Fig 7. The principal model of social factors of the state development

Upon methodological description and methodical generalization of the political, economic, and social environment of the balanced development of the state and society and after evaluation of the integral dependency of political, economic and social factors of this environment, it is possible to model the system of internal threats of the regional cooperation security with Lithuania's integration into NATO and the EU and to prepare a principal model of internal threats that joins together threat groups in time and space [2]; the groups are presented in Fig.8. 
Political threats; Economic threats; Social threats

Fig 8. The principal model of internal threats of the state

Having compared the principal model of the state and society development with the principal model of internal threats of the development of the economy and national market, it is possible to determine the methodological dependency of the balanced development of the society, which is characterized by the integral totality of political, economic and social factors [1]. Methodology of research of that totality forms premises for presenting the dependency of principal models, which is expressed taking that:

$>$ the political environment of the country has a direct effect on the changes of social threats;

$>$ the economic environment of the country affects directly the changes of political threats;

$>$ the social environment of the country exerts a direct influence on the changes of economic threats.

The provisions listed are described by mathematical models, which express the functional dependency of integral factors [8]. The results of integral dependency of political, economic, and social factors are characterized in fixed time and space by the national state budget (income and expenses), the relation of export and import of the national market as well as the GDP per capita, as an indicator of the EU development [12].

\section{The Balanced Development of the State and Society}

Currently, the development of our economy and national market is under the effect of the external and internal political, economic and social environment of the country [2]. The political decisions adopted are coordinated at the EU and NATO institutions; they affect the factors of economic development of the national economy and market, and, frequently, the adopted political decisions do not comply comprehensively with the security of the society development, which does not guarantee the private security of human labour and life as well as family development in Lithuania and abroad [13]. On the other hand, the freedom of the individual and his family is grounded on work, which in macroeconomics is expressed by the GDP, and on the basis of the European Research of Values [ERV], during which (1990-2001) it is taken that the index of economic development of various European countries is the GDP per capita per year, therefore three types of labour values and approaches were distinguished that are of special importance under the conditions of integration and globalization, namely [6]:

> labour as value is important for the life of the individual and the development of his family;

$>$ social labour concept;

$>$ importance of separate labour aspects for the development of the intellectof the individual and for the use of his individual opportunities.

At present the most vulnerable individual is in the Lithuanian countryside, where over 31.8 percent of the population of the country reside, while about 21 percent of the population work in the agriculture and forestry [7]. The natural resources of Lithuania correspond to the methodics for the balanced development of the society. On the territory of Lithuania, the natural conditions are favourable for rearing of animals and poultry, fed with fodder crops and grass, as well as for fish rearing in water basins and for fur breeding. Rather low pollution of the soil, water and air forms the real conditions for the development of the production of ecological agricultural products. Experience of the Baltic region countries shows that agricultural production in our countryside may be developed along non-traditional trends [14]. Article 47 of the Constitution of the Republic of Lithuania foresees that "Land, internal waters, forests, and parks may only belong to the citizens and the State of the Republic of Lithuania...", and Article 48 declares that "Every person may freely choose an occupation or business, and shall have the right to adequate, safe and healthy working conditions, adequate compensation for work, and social security in the even of unemployment..." [15]. The rural population, however, as well as urban people endure the most difficult period of their existence [7]. The incomplete land reform and the inefficiently functioning land market impede the natural growth of farms, reduce their competitiveness on the home and foreign markets. The normative acts of the EU foresee that "Chapter II, Agriculture, Art 38 p. 1. The common market also encompasses agriculture and trade in agricultural goods. "Agricultural goods" are farming, cattle-breeding and fish-rearing products and directly related primary processing products." [16]. Even though the EU countries foresee the reduction of subsidies for agriculture, the farmers, however, each year receive, on the average, over EUR 1000 of the State aid per hectare of arable land. According to the data of the Economic Cooperation and Development Organization (2002), part of the State aid has constituted analogously: in Lithuania - 18 percent, Poland -28.5 percent, the EU countries - 45 percent, these are the 
reasons, impeding the land market to operate efficiently in Lithuania [7]. Today, the efficiency of activity is predetermined and will be predetermined in the future by the rational use of progress, which guarantees the constant increase in labour efficiency of people, the reduction in the cost price of production and the increase in wages relative to the rates of efficiency. The efficiency of the use of progress may be calculated methodically in each concrete case by applying a functional integral mathematical model [2]:

$$
E_{p-j}=\left[\left(c_{i}+e_{n} U_{i}\right)+\left(c_{j}+e_{n} U_{j}\right)\right] A_{j}\left(f_{t} f_{e}\right),
$$

where $E_{p-j^{-}}-$the annual efficiency of the use of progress in the Lithuanian rural or urban localities when manufacturing a new product (j);

$c_{i}$ - the cost price of the old product manufactured in the Lithuanian rural and urban localities (i);

$e_{n}$ - normative efficiency rate (projected is equal to 0.143 when the capital repayment is 7 years)of capital (implementation and repayment of investments into progress);

$U_{i}$ - partial investments into capital per manufactured unit of old products $(i)$;

$c_{j}$ - the cost price of a new product $(j)$ planned for manufacturing in the Lithuanian rural and urban localities;

$U_{j}$ - partial capital investments per unit of a new product planned for manufacture;

$A_{j}$ - the annual production programme, upon the implementation of the progress of the planned new product $(j)$ for ensuring the production efficiency, and its sales volumes on the national and international market for the planned investment repayment period;

$f_{t}$ - temporal integral function; $f_{e}$ - spatial integral function.

While developing the balanced labour activity of people in the Lithuanian rural or urban localities in order to ensure the efficiency of the use of progress in each separate case, which in the perspective in the national, EU and world market would create the real conditions for optimization of the labour activity of the rural and urban population and the rational use of the natural, material and human resources, it is necessary to solve the especially complex and comprehensive tasks, formed by the global economy [17]. For solution of these tasks and optimization of the activity, a methodological sequence and its application methodics as well concrete methods are recommended, with the application of which in a specific way it is possible to (a strict dependency of economic efficiency, which is calculated by applying a functional integral mathematical model 1) [2]:

$>$ select an optimum variant for the use of progress so that the partial capital investments per product unit $(j)$ should be the least;

$>$ markedly reduce the cost price of a new product $\left(c_{j}\right)$;

$>$ ensure the rapid increase of the annual production programme $\left(A_{j}\right)$ and sales volumes on the national and international market;

$>$ solve the requalification of the rural and urban population;

$>$ increase labour efficiency - to modernize jobs, establish new ones, provided that wages increase slower as compared to the labour efficiency increase rates;

$>$ balance price changes of material resources and calculate their necessary optimum volumes for the development of the annual production programme $\left(A_{j}\right)$;

$>$ ensure the financial stability (on the basis of sales and purchase agreements);

$>$ forecast the integral space function/market factors/;

$>$ implement and permanently improve the quality management system (at a level of ISO standard series);

$>$ others, i.e. comprehensive tasks of the universal management system that should be solved permanently.

The structure and complexity of solutions of comprehensive tasks consist of the permanent increase of labour efficiency and wages, but labour efficiency should increase more rapidly than wages (what is being frequently violated in practical activities, this is that wages are not increased, in general). These main methodological requirements comply with the actual environmental conditions to ensure the balanced development of the national economy in time and space (in Lithuania, in the branch of the national economy and the economy, on the national, EU and international markets) [18]. This is a comprehensive task of special purpose in time and space [11].

The use of progress in the life and work of the individual, the development of his family and the optimization of the collective activities in a single organization create conditions for the development of the labour activities and the strengthening of democracy under the conditions of integration and globalization, under which it would be possible to ensure the balanced development of the state and society as 
well as the life quality of people in time and space (in Lithuania, the EU and the world). However, the processes of the development of democracy and progress are integral and have the functional dependency. The function of the development of progress and democracy may be expressed by function of labour and the added value of labour, which is described by a functional integral mathematical model [2]:

$$
P f(D)=d f(d p v) f_{t} f_{e^{\prime}}
$$

where $P$ - the use of progress, designed for ensuring the balanced development of the state and society;

$f(D)$ - the function of democracy, intended for ensuring the balanced development of the state and society, and this function is expressed by the system of normative acts of Lithuania;

$d$ - the work, aimed at ensuring the balanced development of the sate and society: creation of the national product, production and its sale on the national, EU and international markets;

$f(d p v)$ - the labour value added function, designed for ensuring the balanced development of the state and society, expressed by the integral factors of the global economy - "free movement" of: capital, goods and services, labour force in time and space (in the world, EU, Lithuania);

$f_{t}$ - temporal integral function; $f_{e}-$ spatial integral function.

The development of the state and society is the process, based on the balanced economy, the real result of which in fixed time and space is expressed by the life quality of the individual and his family. The life quality of people is the extended methodological conception of the management of the state and society development, therefore it complies with the conception of an indicator. This indicator is a useful measure in simplifying, specifying quantitatively, generalizing the huge flows of information, creating the effective feedback between the entities and objects of society and the entities and objects of the state, revealing political, economic and social fields, where we are acting optimally, as well as focusing on areas that need to be given attention in optimizing the human activity in time and space [14]. This management methodological conception is used in seeking to reduce the number of complicated interrelations, bringing them to methodical formulation, facilitating evaluations between the state and society as well as society and the state under the conditions of the world global economy, globalization and integration into NATO and the EU [19]. On the other hand, an indicator is a quantity or measure, providing information on the dependency of the global systems, or in this case on the integral relationship of the political, economic and social processes of the development of the state and society, which is methodologically characterized by the specific group of factors like (the integral dependency of political, economic and social factors that according to the theory of probability is expressed by a functional integral mathematical model 2) [2]:

$>$ progress - a new product, new materials, new technologies, new means of activity, new labour efficiency (job modernization, establishment of new jobs, permanent training of the staff, proportionate increase of labour efficiency and wages according to the efficiency dependency) for the optimization of the activities of the individual organization on the national and international market, increase in the real income of the individual and the balanced development of his family (accumulation and development of capital - a life quality guarantee);

$>$ democracy-freedom of the balanced development of the activities and life of the individual and his family (from anarchy to the regime to ensure the balanced development of the state), which guarantees the capital accumulation and development in time and space;

$>$ labour - the intellectual and physical activity of the individual that is expressed by the capital accumulation and development to ensure the balanced activities of the state and society in time and space, and to integrate the demand - supply on the market by the principle of exchange, which should ensure the improvement of human life quality;

$>$ added value of labour-real income of the individual received for intellectual and physical labour in fixed time and space that has a constant effect on capital accumulation and development as well as the balanced development of economy at the level of the national, EU and world market;

$>$ time - evaluation criterion, intended for identification of the added value of labour in space (on the national and international market);

$>$ space - evaluation criterion, intended for identification of the place of activities (for forecast of factors on the national and international market).

All the listed integral factors for evaluation of the balanced development of the country's economy, the state and society and their calculated normatives create real conditions for optimization of the work and life of the individual, his family development, and the activities of the collective body in the organization; also for developing the balanced national economy and 
strengthening of the regional cooperation security in the common space of NATO and the EU as well as on the market of global economy of the world [20]. Therefore it is possible to note that the labour of the Lithuanian people and the national product created in the course of labour processes as well as the development of labour activities is the main object and subject of the management of consistent policy of the balanced development of the country's economy and national market [21].

The science of management explores and responds to all comprehensive questions, whereas in practice it does not provide optimum solutions, since the latter must be prepared and adopted by the people taking positions in the State institutions, thus improving the integral environment for the development of Lithuania and society and ensuring the regional cooperation security upon Lithuania's integration into NATO and the EU [22]. This is a long-term and constantly developing process, which ensures the balanced development of the country's economy and national market in time and space. The participants of this process are all national and international market actors. The solution of these tasks is aggravated by internal factors of the economy of Lithuania and national market environment and external factors of Lithuania, which are on the constant change due to the political, economic, and social environment, as well as due to the integral dependency of the development of the global economy and the EU market factors in time and space [23].

Due to the consequences resulting from the development of the global economy, still new comprehensive tasks arise for the national state institutions [24]: how to ensure the national security of the balanced development of the state and society as well as the private security of our people and their families [25]. It is necessary to stress that the individual of Lithuania and his family do not have at present and will not have in the future the real conditions and opportunities for tackling very complex and comprehensive tasks while developing their labour activities, since the policy of economy and market is an integral part of Lithuania's economy and the social environment of the life of people [26]. Therefore it is necessary to analyze and forecast the national security of Lithuania's development, which is affected and will be affected in the future by political, economic and social factors [12].

After generalization of the results obtained during the comprehensive research, it is possible to state that political-economic and economic-political factors to- date in Lithuania are closely integrated, whereas social factors are "aloof" (as if left to themselves and for freedom of the individual and his family development that is not free, since it depends on the summary results of the state development).

Therefore it is possible to indicate the result: unemployment, the irrational use of the national resources and the slow rate of the use of progress as well as the non-competitive production of the national product in the national economy, its inefficient realization in the national and international market, therefore the individual and his family in our country are unsafe politically, economically, and socially, or the private security does not conform to the principal provisions of the Lithuanian national security strategy in the real life [20].

\section{Private Security of the Development of the Individual and Family}

Security of the development of the individual and his family is an integral part of national security. Lithuania is not an exception [26]. When analyzing the rational use of the natural resources of the country, it was identified that at present our country is in possession of 38,3 thous. ha of lands, consisting of plots, which have lost their economic value, have the damaged or completely destroyed soil cover, the changed hydrological regime or otherwise degraded areas [14]. Nevertheless, this is our wealth, which is the guarantee of private security in Lithuania for the individual and family [26]. This property is evaluated by the agricultural activity, and the said activity affects the scale of biological property in the general part of GDP. The biological property consists of live animals and plants [27], whereas the agricultural produce are products generated from the biological property (ibid). Labour of Lithuanian people is expressed by the added value of labour for identification of the cost price and price per production unit on the national and international market, for which the individual of Lithuania receives real income, which affects directly the purchasing power on the market and the level of the participation of the individual in the market. This level to-date is low, since the purchasing power of the urban and rural population is very low in the common EU market [2]. The processes of globalization and integration as well as the EU changes and normative acts relevant to the development of these changes only partly foresee the support to the development of the labour activity of Lithuanian rural and urban people, since the major part of complex and comprehensive tasks are transferred for solving to national state 
institutions [26]. The said institutions delegate their competence to the individual and his family, and even local self-management institutions are not ready to implement the EU aid funds that will reach us already in the second half of 2004. Here numerous comprehensive tasks come forth and they are specified by [10]: the use of progress, restructuring, specialization and cooperation of activity trends, employment, professional preparation, self-improvement and raising of qualification of people, modernization of organizations, implementation of ISO 9000 series standards, free movement of capital, goods and services, and labour force both from the West and the East, etc. [7]. The necessity arises for state administration insititutions to ensure the market of perfect competition at the present moment by the system of normative acts and their practical activities [26]; [9]; [28], since only the integral factors of the balanced development of our economy and market will predetermine in the future the optimization opportunities of the activity of the urban and rural population of Lithuania and the general security of development [13]. These processes are characterized by the geopolitical situation of Lithuania, which is elucidated by the EU and NATO experts as well as specialists of our country [10], since the guarantee of security of the national economy and market development is the life quality of our people and private security of the separate individual and his family. The quality of life and labour of people and of life of their families is estimated as a function of property accumulation and its development, which is expressed by a mathematical model [2]:

$$
K_{i}=\left(N T_{i}+I_{i}+P_{i}\right) f_{t} f_{e},
$$

where $K_{i}$ - property (capital) of the individual and his family, designed for ensuring the balanced development of Lithuania's economy and market;

$N T_{i}$ - real estate of of the individual and his family, intended for ensuring the balanced development of economy and market;

$I_{i}$ - investments of the individual and his family activities, aimed at ensuring the balanced development of economy and market;

$P_{i}$ - real income (from the activities) of the individual and his family is money that the individual and his family may freely dispose of (use) - develop in the balanced development of economy and market;

$f_{t}$ - temporal integral function; $f_{e}$ - spatial integral function.

The rate of progress use depends on the forms of capital accumulation and development, the integral interaction of its functions with the factors of the development of the Lithuanian balanced economy and national market as well as on the real internal and external environment, since the integral dependence of functions is expressed by labour and its real value on the market.

Mental and physical work of the individual is the main factor, which constantly affects the accumulation and development of capital, whereas integral processes form the real conditions for acceleration of the balanced development of the state, society and national economy in time and space. The balanced development is characterized by the form of property and its constituent parts, which are expressed (labour economic results are calculated and their dependency is expressed by matematical model 3) by the objects of private security management of the individual and his family as well as integral processes of dependency [2]:

$>$ capital - the result of the periodical activity of the individual: the summary volumes of private property of the individual and his family in time and space, on which the balanced development of the country's economy and national market, the internal threats of security and their dependence on the external threats of security are dependent;

$>$ real estate - the result of the periodical activity of the individual: private natural resources, basic funds and their assets and liabilities (buildings, structures, means of activity, etc.), the value of which increases in time and space (if usedimproperly, they may decrease as well, therefore it is the object of national and international business management);

$>$ investments - the result of the periodical activity of the individual: subjects, objects and processes of management, in the course of which progress is used, purchases and sales are made, real income is received in time and space, the intellect of the individual is developed and employed permanently, this ensuring the accumulation and development of private capital (as the basis of the balanced national economy);

$>$ money - the result of the periodical activity of the individual: real income, expressed and available in the form of money at bank or in cash (in different forms), which the individual or his family may freely dispose of in time and space or invest into real estate and investments for the development of activities on the national and international markets;

$>$ time - a criterion for property accumulation and development in space; 
$>$ space - place for property accumulation and development (on the national and international markets).

Capital accumulation and development is based on the balanced development of national economy, which is the basis of the balanced development of the state and society, as the integral results of political, economic and social factors, ensuring (or not ensuring) the private, national and regional cooperation security both in time and space (inside and outside the country). Today, the political, economic and social factors of the development of our state and society restrict sufficiently the accumulation and development of the property of people, since meanwhile the function of capital development in the territory of Lithuania has a negative effect on the life quality of people: income and the purchasing power is low, the labour activity is not efficient and does not conform to the added value of labour under the conditions of the national, EU and world market. Due to the mentioned factors, the development of the Lithuanian economy and national market is not balanced and slow, because it does not comply with the political, economic and social preconditions for the use of progress and democracy development: to invest and develop the labour activities under the conditions of the integral development of Lithuania, the EU and the world [2]. These conditions to-date are also limited by the existing system of normative acts of the country [9], which does not stimulate the modernization of jobs and the establishment of new ones in the economy and national market, thus impeding essentially the rational use of natural, material and human resources of the country [7]. Positive and negative human labour results in our economy and national market evidence the influence of of global economic factors of the world as well as of integrationand globalization processes on the development of the country and society, the results of which are generalized by macroand microeconomic factors of the economy in the common space of NATO and the EU.

Macro- and microeconomic factors are values subject to calculation in fixed time and space, whereas the precision of calculations depends on the constantly updated data bank, into which real results of human activity are introduced [2]. It is noted that statistical indicators in our country differ significantly from the real macro- and microeconomic indicators, which in fact are not difficult to be calculated in the fixed time and the territory of Lithuania (to calculate the general arithmetical mean of the indicator per capita or family in the country) $[9,5,11,28]$. These data are important for predicting the rate of the use of progress in
Lithuania and its regions, since these forecasts are necessary for preparation of investment strategy so as to ensure the balanced development of the economy of the country and national market as well as national and private security in the space of NATO and the EU $[9,5,11,28]$. On the other hand, the balanced development of of our state and society is based on the political, economic and social environment, which is affected by the factors of global economy. These factors increase in the essence the social, political and economic threats in Lithuania [2].

During research it was identified that political environment of the development of society was developing social threats, whereas economic environment political threats and social environment - economic threats [26]. Such integral dependency of threats in the development of Lithuanian economy and national market strengthens the internal threats of national security of the country and simultaneously does not stimulate the security of the development of our society, family and human life [2]. These processes give rise to the ovjective concern, since integration into the common space and market of the EU alone does not ensure the private security of the development of the indivdual of Lithuania and his family [9, $5,11,28] ;[26]$, therefore the national administration institutions already now must radically solve the long ago formed problems of Lithuanian people and create favourable conditions for the development of labour activities in the total territory of the country: use all the available resources for the development, that is create, manufacture and sell the competitive national product on the home and international market. Only such activity will ensure the accumulation and development of capital in the life of our peoplw, will improve the life quality of the separate individual and his family, while this integral function will also strengthen the national security of the development of Lithuania [2]. Management methodology, methodics and methods do not foresee any other opportunities for the balanced development of Lithuania's economy. This is based on the already available scientific research data by Lithuanian and foreign authors, scientific literature and other sources as well as on management methodology, methodics and methods for ensuring the security of the balanced development of the state and society, since real environment and reality is not and cannot be stable [25]. Due to this reason, problems of regional cooperation security upon Lithuania's integration into NATO and the EU remain of actual importance, and we will be obliged to analyze them constantly and take optimum political, economic and social solutions for tacckling integral 
tasks, since the Baltic Sea area is and will remain one of the most important global objects of the management of the development of the global economy of the world and market entities (in Europe and the world) [20]. Therefore it is important to explore the internal threats of the regional cooperation security, to identify their functional dependency, to model their integral forms and models as well as to predict the private, national, regional, continental and the world community development security of the balanced development of the state and society.

National security is the balanced development of the state and society, the basis of which is formed of the balanced development of national economy, the private security of the life and labour of the individual and his family development, the activity of the collective in the organization, accumulation and development of captal for improvement of the level of human life. Private and national security is ensured by the weakening of internal and external threats with Lithuania's integration into the common space of NATO and the EU. This is the key task of the national state, the positive results of whose solution guarantees the state sovereignty [23], economic security [5], regional security [5] as well as the balanced development of the state and society (in Lithuania, the EU, and the world) [12].

\section{Conclusions}

Methodological principles for researching the internal threats of the regional cooperation security, their implementation methodics and methods under the conditions of Lithuania's integration into NATO and the EU revealed the broad opportunities for comprehensive analysis of the internala threats of national security in time and space. The accumulated and described material of research performed create conditions for formulation and provision of the generalizing conclusions.

1. The balanced development of the state and society will be ensured by the uniformity of political, economic and social factors in the common space of NATO and the EU.

2. The development of human activity in Lithuania and the increase in the added value of labour guarantee the competitiveness of the national product and GDP growth.

3. Private security of the individual and family is expressed by the dependency of the accumulation and development of capital that creates the real conditions for the development of progress under the conditions of Lithuania's integration into NATO and the EU.
4. Strengthening of national security depends on the results of the balanced development of the state and society, which are intended for weakening of the internal threats and stabilization of the regional cooperation security development.

5. The road of integration into the EU and NATO, selected by the Lithuanian people is based on the methodological principles of the national security development and is correct politically, economically ans socially, however, national institutions must formulate and approve the priorities of the balanced development of the country's economy and national market, the implementation of which would ensure the weakening of the internal threats of security and the life quality of people in time and space.

\section{References}

1. Melnikas B. Transformations. Vilnius: Vaga, 2002. 750 p. (Monograph in lithuanian).

2. Makštutis A. The principles of strategic Management. Klaipėda: KU, 2001. 380 p. (Monograph in lithuanian).

3. Documents $-\mathrm{XX}$. World and Lithuania. Vilnius: Kronta, 2002. 391 p. (in lithuanian).

4. Bauman Z. Globalization: The Human Consequences. Cambridge: Polity Press, 20002. 208 p.

5. Buzan B. People, States and Fear: An Agenda for International Security studies in the Post-Cold War Era. Second edition. Copenhagen: PH, 1991. 469 p.

6. Europe and We. Vilnius: Gervelè, 2001. 268 p. (Monograph in lithuanian).

7. Lithuania in the World Context (Experts' view). Vilnius: Mokslo aidai, 2003. 416 p. (in lithuanian).

8. Makštutis A. Activity Management: Theory and Practice. Vilnius: Petro ofsetas, 1999. 511 p. (Monograph in lithuanian).

9. Lithuania: Statute Book of Lithuania. Vilnius: Saulužè, 2002. 630 p. (in lithuanian).

10. Quality Management in the Process of Integrating Lithuania into the European Union. Conference Materials, 27-28 November, 2002. Kaunas: Technologia, 2002, p. 69-73.

11. Vilpišauskas R. Integration into Europe: Baltic States and EU. Vilnius: Arlila, 2001. 158 p. (in lithuanian).

12. Grebliauskas A. Evolution of World - XX. Kaunas: VMU, 2001. 196 p. (in lithuanian).

13. Management of Organizations: Systematic Research. No. 24. 2002. ISSN 1392-1142. Kaunas: VMU, 2002, p. 8390.

14. Čiegis R. Development and Environment: View of Economics. Vilnius: Aldorija, 2002. 692 p. (in lithuanian).

15. Lithuania: Constitution of the Republic. Vilnius: Saulužè, 1994. 64 p. (in lithuanian). 
16. Europe Union. Vilnius: Eugrimas, 1998. 403 p. (in lithuanian).

17. Ньюстром Д., Дэвис К. Организационное поведение. Поведение человека на рабочем месте. Санкт-Петербург: Изд-во „Питер“, 2000. 447 р.

18. Сенге П. М. Пятая дисциплина. Искусство и практика самообучающейся организации. Москва: ЗАС „Олимп - Бизнес“, 1999. 406 р.

19. Grigas R. Nation of Sociology. Vilnius: Rosma, 2001. 233 p. (Monograph in lithuanian).

20. National Strategic of Security. Vilnius: KAM, 2002. 22 p. (in lithuanian).

21. Schultz T.W. Investing in People. The Economics of Population Quality. Los Angeles: University of California Press, Ltd., 1981. 192 p.

22. Denhardt R.B. Theories of Public Organization. Third edition. Arizona: Copyright by Marcourt Brace \& Company, 2000. $304 \mathrm{p}$.
23. Thery Today of International Relations. Edited by Ken Booth and Steve Smith. Polity Press in association with Blackwell Publishers Ltd., 1997. 352 p.

24. Tatsachen über Deutschland. Frankfurt/Main: SocietätsVerlag, 2002. 568 p.

25. Schuman R. Pour L'Europe, Troisieme edition. Paris: Les Editions \& Guillaume Briquet, 2000. 160 p.

26. Lamentowicz W. Panstwo Wspolczesne. Warszawa: SP, 1993. 120 p.

27. Accounting and Finances on the Way of Integration into European Union. International Scientific Conference Proceedings. 21 - 22 November, 2002. Kaunas: Akademija, 2002, p. 106 - 111.

28. Žigaras F. Baltic States: Security and Defence $1990-$ 2002. Vilnius: KAM, 2002. 346 p. (Monograph in lithuanian). 